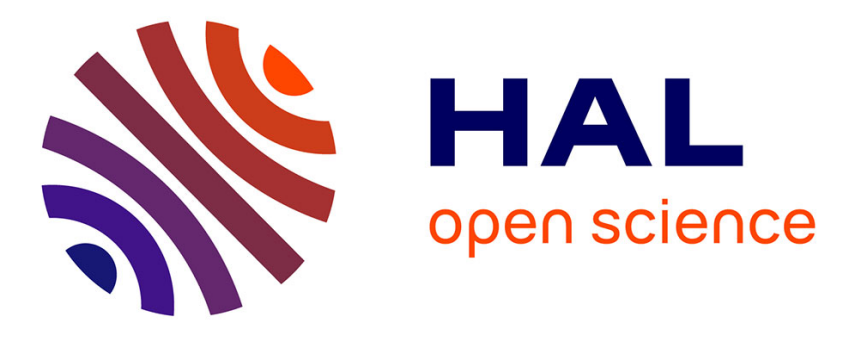

\title{
Understanding and managing soil biodiversity: a major challenge in agroecology
}

Philippe P. Lemanceau, Pierre-Alain Maron, Sylvie Mazurier, Christophe Mougel, Barbara Pivato, Pierre Plassart, Lionel Ranjard, Cécile Revellin, Vincent Tardy, Daniel Wipf

\section{To cite this version:}

Philippe P. Lemanceau, Pierre-Alain Maron, Sylvie Mazurier, Christophe Mougel, Barbara Pivato, et al.. Understanding and managing soil biodiversity: a major challenge in agroecology. Agronomy for Sustainable Development, 2015, 35 (1), pp.67-81. 10.1007/s13593-014-0247-0 . hal-01208787

\section{HAL Id: hal-01208787 https://hal.science/hal-01208787}

Submitted on 28 May 2020

HAL is a multi-disciplinary open access archive for the deposit and dissemination of scientific research documents, whether they are published or not. The documents may come from teaching and research institutions in France or abroad, or from public or private research centers.
L'archive ouverte pluridisciplinaire HAL, est destinée au dépôt et à la diffusion de documents scientifiques de niveau recherche, publiés ou non, émanant des établissements d'enseignement et de recherche français ou étrangers, des laboratoires publics ou privés.

$$
\text { Copyright }
$$




\title{
Understanding and managing soil biodiversity: a major challenge in agroecology
}

\author{
Philippe Lemanceau • Pierre-Alain Maron • Sylvie Mazurier • \\ Christophe Mougel • Barbara Pivato • Pierre Plassart • Lionel Ranjard • \\ Cécile Revellin • Vincent Tardy $\cdot$ Daniel Wipf
}

Accepted: 22 July 2014 / Published online: 9 September 2014

(C) INRA and Springer-Verlag France 2014

\begin{abstract}
Soils are living environments in which particularly abundant and diverse microbiome and fauna are evolving. The resulting biological functioning has a direct impact not only on soil fertility but also on a series of ecosystems services. Thus, microbial communities are involved in geochemical cycles in which microbial enzymes catalyse the different steps. Modulation of the corresponding activities is essential as these affect plant growth and environmental quality. In general, biodiversity affects both the productivity and stability of agroecosystems. It is therefore of paramount importance to take soil biodiversity and biological functioning into account when designing cropping systems and evaluating their impacts. The progress achieved in soil microbiology in recent years now makes it possible to propose analyses of soil biology, as has been feasible for many years for soil physicochemistry. These analyses obviously require the use of standardized procedures for soil sampling, measuring the abundance and diversity of the microbial communities, as well as the identification of bioindicators. Similarly, referential systems need to be established to interpret these analyses and diagnose the
\end{abstract}

This manuscript is the English version of the chapter 'Qu'attendre des recherches en microbiologie du sol pour la connaissance et la gestion de la fertilité des sols?' by Lemanceau et al. published in French in the book Fertilisation et environnement, Editions 3 Quae-Acta, 2014, ISBN (Quæ): 978-2-7592-2055-7 and ISBN (Acta): 978-2-85794-280-1.

P. Lemanceau $(\bowtie) \cdot$ P.-A. Maron $\cdot$ S. Mazurier $\cdot$ B. Pivato $\cdot$

P. Plassart $\cdot$ L. Ranjard $\cdot$ C. Revellin $\cdot$ V. Tardy

INRA, UMR 1347 Agroécologie, 17 rue Sully, BP 86510,

F-21065 Dijon cedex, France

e-mail: philippe.lemanceau@dijon.inra.fr

C. Mougel

INRA, UMR 1349 IGEPP BP35327, F-35653 Le Rheu cedex, France

D. Wipf

Université de Bourgogne, UMR 1347 Agroécologie, 17 rue Sully, BP 86510, 21065 Dijon cedex, France biological status of soils, and, more especially, to determine whether the obtained values are within the range of variations normal for a given soil type and land use. Great progress to standardize such procedures and establish referential systems has been achieved during large-scale research programmes carried out to characterize biodiversity on national and European scales. These diagnostic elements need to be accompanied by recommendations. The aim of ongoing research is thus to propose aids for decision-making, based on the results of biological analyses, so attempts can be made to monitor and manage biodiversity to satisfy soil fertility requirements and ensure the ecosystem services expected of soils.

Keywords Agroecology $\cdot$ Biodiversity $\cdot$ Microbial communities $\cdot$ Plant growth and heath $\cdot$ Soil biology $\cdot$ Soil fertility

Contents

1. Introduction

2. Diagnosis of the microbiological state of soils

2.1. Difficulties in studying soil microbiome

2.2. Biodiversity-activities-functions

2.3. Bioindicators

2.4. Need for standardized referential systems

3. Ecological engineering

3.1. Microbial inoculation

3.2. Orienting the microbial populations/communities

4. Conclusions and prospects

\section{Introduction}

The sustainable management of soils has to take into account both agronomic and environmental challenges. Agriculture 
must necessarily maintain high and stable yields, and, at the same time, make economic use of fossil energy, inputs and natural resources and integrate biodiversity into the very process of production (Inra 2010). The implication is to produce more and better. These challenges require the development of innovative agricultural systems which use fewer inputs, are more respectful of the environment and deliver the expected ecosystem services. This will inevitably rely on a paradigm shift and reconciliation of the long-lasting conflict between agriculture and ecology. Until recently, ecology has essentially focused on poorly anthropized zones, and agriculture has attempted to adapt the environment to the crop, the extreme being soil-less crops where growing substrates serve merely as a support, and nutrition is provided by mineral solutions. The confrontation between agriculture and ecology stems from the significance of soil fertility which, for the agronomist, implies productivity and mineral nutrition, and, for the ecologist, biological equilibria and regulation.

The above-mentioned paradigm shift therefore consists of adapting the crop to the environment by making the best possible use of biotic interactions, particularly between roots and microorganisms (Fig. 1). Such biotic interactions should

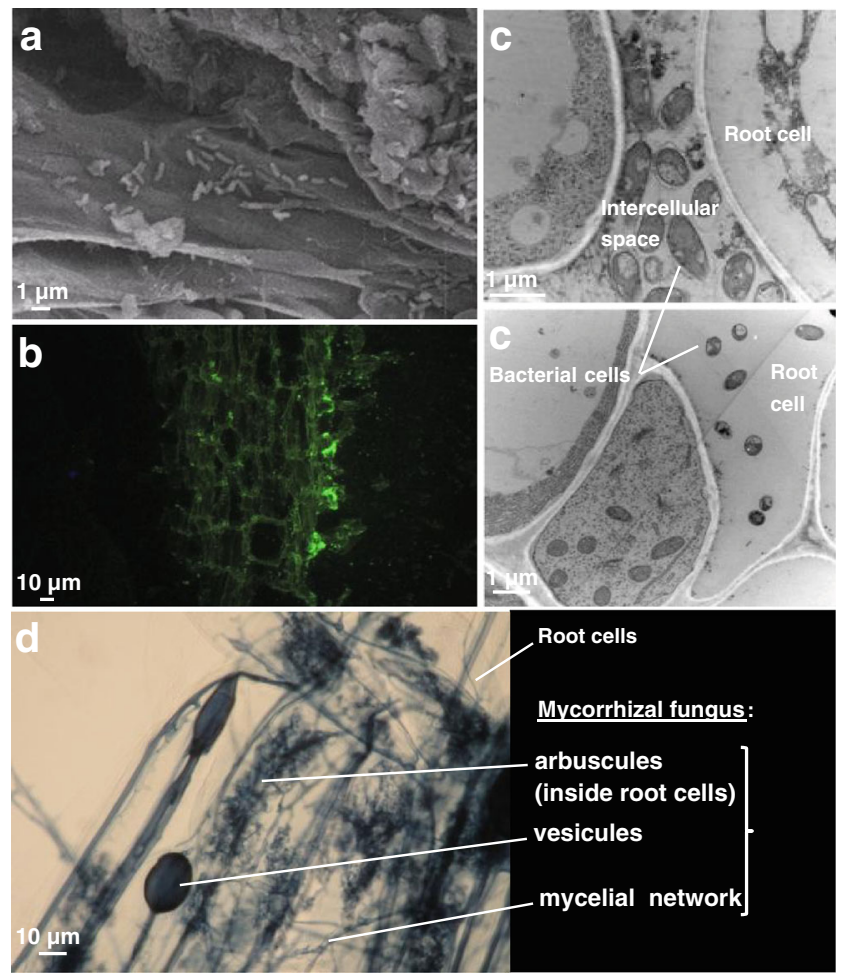

Fig. 1 Illustrations of close interactions between plant roots and soil microorganisms: surface of medic root colonized by soil bacteria (rods of c.a. $1 \mu \mathrm{m}$ ) as observed by scanning electron microscopy (a) and confocal laser scanning microscopy (b) INRA/L. Avoscan ${ }^{\circ}$. Avoscan; cell and intercellular spaces (apoplasm) of medic root colonized by soil bacteria as observed under transmission electron microscopy (c) INRA/L. Avoscan ${ }^{\circledR}$; leek roots colonized by arbuscular mycorrhizal fungus Rhizophagus sp. as observed by optical microscopy (d) INRA/A. Colombet ${ }^{\circ}$ contribute to plant nutrition and health, and, thus, to soil fertility. The contribution of soil microorganisms to nutrition is linked to their involvement in geochemical cycles (mainly those of nitrogen and carbon, but also of iron and phosphorus), through the reactions that they catalyse as a result of enzyme syntheses. For the nitrogen cycle, these enzymes are well known, from the introduction of atmospheric molecular nitrogen into soils via the activity of nitrogenase in the nodules during symbiotic nitrogen fixation by leguminous plants, up to the final reduction of nitrogen oxides to $\mathrm{N}_{2} \mathrm{O}$ (a greenhouse gas) and finally to $\mathrm{N}_{2}$ (Fig. 2). For the carbon cycle, they are less well known as the activities of the constituent enzymes are much more diverse due to the complexity of organic compounds and their degradation products. The functioning of both cycles has a direct impact on plant nutrition and also on the environment. Thus, the cultivation of leguminous crops helps to enrich soils in nitrogen while the reduction of nitrogen oxides which can result in $\mathrm{N}_{2} \mathrm{O}$ emission contributes to the greenhouse effect. Loss of nitrogen through emissions of this gas and of $\mathrm{N}_{2}$ is detrimental to soil fertility. Similarly, the mineralization of organic compounds in soil releases nutritive elements for the plant, but also contributes to $\mathrm{CO}_{2}$ emissions detrimental to the environment. Soils also harbour numerous microorganisms which produce antibiotics or, at a more general level, molecules reducing the saprophytic growth of plant pathogenic agents or eliciting defence reactions in plants. Overall, the microbial biodiversity of soils contributes not only to the productivity but also to the stability (resistance/resilience) of the agroecosystem and thus to its sustainability.

A major operational challenge for microbial ecology research is therefore to provide information allowing the diagnosis of soil biodiversity and biological functioning. This necessitates an effort to standardize sampling and analytical procedures, to develop appropriate bioindicators and to establish referential systems for interpreting the results. Such information relies on prior descriptive studies of biodiversity, determination of the relationships between biodiversity, activities and biological functioning, and characterization of the effects of environmental filters on diversity and on the above-mentioned relationships. The ultimate challenge is to apply the resulting diagnosis for decision-making in the form of recommendations for monitoring and management of biodiversity to ensure soil fertility and, more generally, to guarantee provision of ecosystem services.

\section{Diagnosis of the microbiological state of soils}

For a long time, soils were mainly considered as a support and a reservoir of the mineral elements needed for plant growth and development. The knowledge required for soil physicalchemical analyses and their interpretation was provided by 


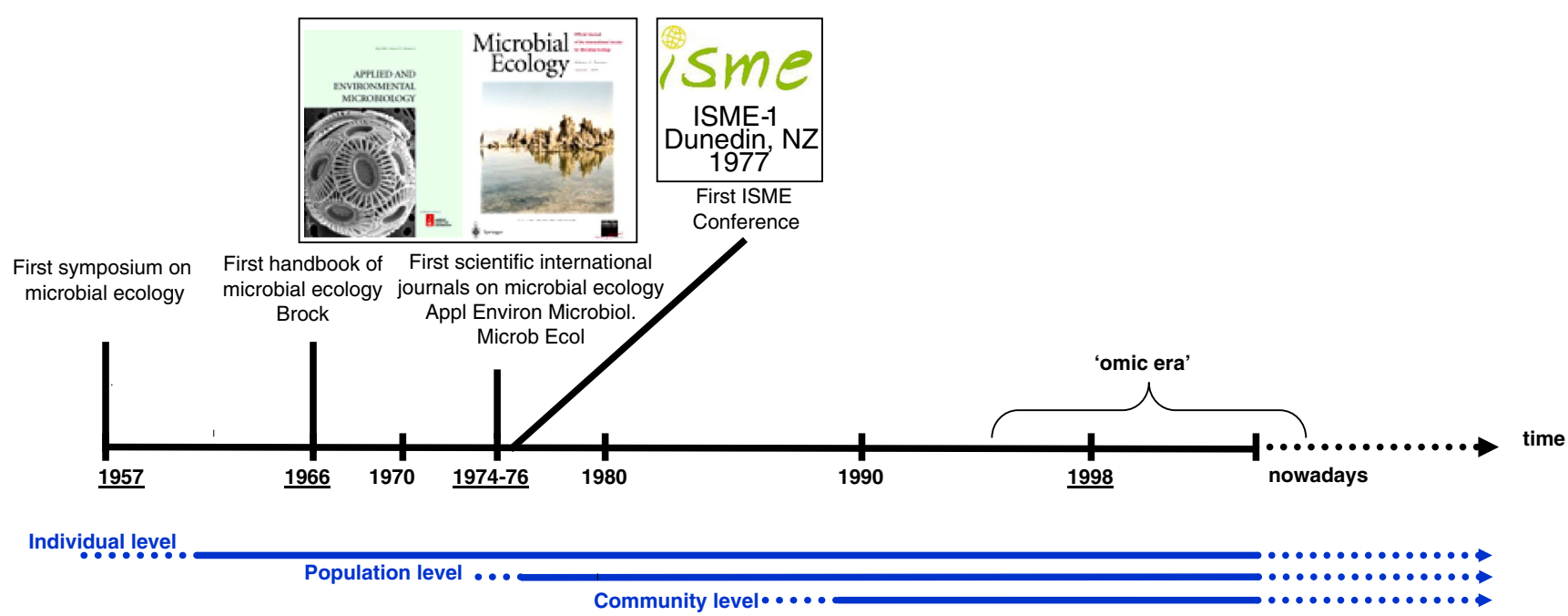

Development of culture media for isolating microbial organisms

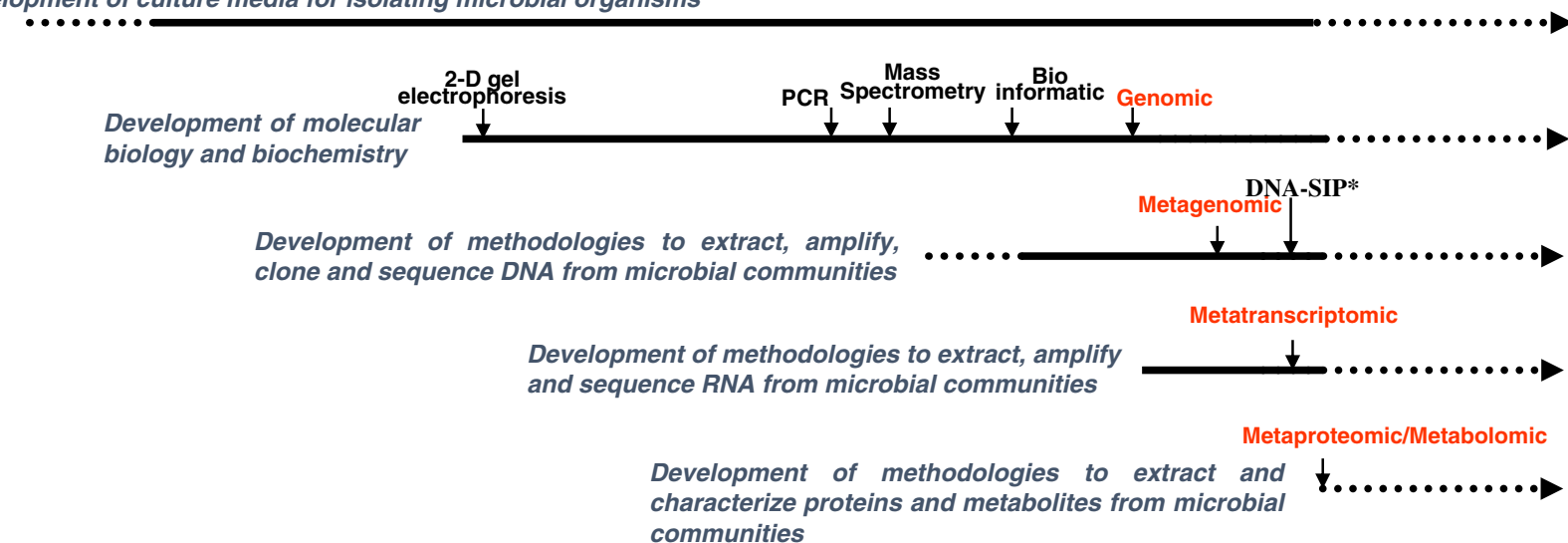

Fig. 2 Principal steps in the development of microbial ecology (from Maron et al. 2007). *DNA-stable isotope probing

extensive research. Awareness of the importance of life in soils (Gobat et al. 2010) and of its effect on plant growth and health then stimulated research in soil biology. As with the physical-chemical analyses, diagnosis of the biological component of soils is a two-step process consisting of analyses followed by their interpretation.

The general relevance of such a diagnosis became apparent during integration of the biotic interactions occurring in soil and rhizosphere to sustainably manage soils and promote provision of ecosystem services (including primary production). Thus, the European Commission clearly identified the need for a better understanding of soil biodiversity and biological functioning, and for the development of bioindicators to allow application of its soil management policy (COM(2012) 46, http://eur-lex.europa. eu/legal-content/EN/TXT/?uri=CELEX:52012DC0046). This should contribute to the instigation of a framework directive for soils, as already exists for air and water. Application of this policy will require appropriate procedures and methods to characterize the biological component of soils, whether or not such soils are used for agriculture.

\subsection{Difficulties in studying soil microbiome}

The delayed development of soil biology analyses, as compared with physical-chemical analyses, is not only due to the late consideration of the biological component of soil fertility. It can also be explained by the very characteristics of microorganisms and soils. Microorganisms, as their name implies, are of microscopic size (in the order of one micrometer for bacteria). Their diversity in soils is huge with about one million species of archaea and bacteria per gram of soil (Bates et al. 2011; Torsvik and Øvreås 2002). Most (more than $90 \%$ ) of these microorganisms cannot be cultured on existing media (Rajendhran and Gunasekaran 2008; Schloss and Handelsman 2003), which meant until recently that they could not be studied. Soil microorganisms are also hidden within the soil which is a heterogeneous but structured matrix, and, thus, hinders access to this biotic component. The heterogeneity of the soil environment containing microorganisms also exists on different scales (aggregate, plot, landscape, country). These various difficulties for a long time only 
permitted a distorted vision of soil biodiversity. This state of affairs can also be linked with the fact that the science of microbial ecology, based on analysis of the interactions between microorganisms and with their environment, is very young ( $\approx 50$ years). The first international colloquium took place in 1957, and the first international magazine was only launched in 1974 (Maron et al. 2007; Fig. 1). Considerable methodological advances, including extraction and quantification of soil DNA, and analysis of its polymorphism have been dedicated to overcome these difficulties, allowing now to obtain a more complete picture of the microbial communities present in soils. In particular, the spectacular reduction of costs, especially of high-throughput sequencing, which fell from 5,292 to 0.06\$ per DNA megabase between September 2001 and April 2013 as a result of methodological developments (http://www.genome.gov/sequencingcosts/), means that eventual access to the totality of soil biodiversity can now be envisaged.

\subsection{Biodiversity-activities-functions}

These methodological advances are facilitating response to the major challenges confronting soil biology research. These challenges are (1) to better understand soil biodiversity; (2) to evaluate the relationships existing between biodiversity, functions, and ecosystem services; and (3) to determine the impact of environmental conditions on soil diversity and biological functioning (Fig. 3). Such research, apart from its academic interest, is of operational value for the management of soil

\section{Environmental filters}

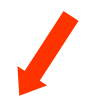

Biodiversity

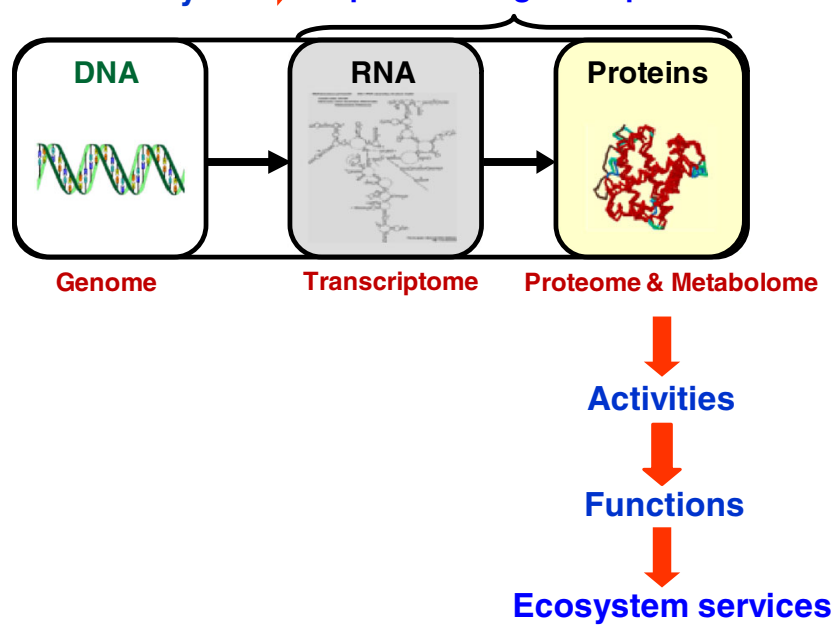

Fig. 3 Diagrammatic representation of the relationship between diversity, expression of genetic potential, activities, microbial functions and, finally, ecosystemic services delivered by soils. Environmental filters impact diversity and expression of the genetic potential of the microflora (project EcoFINDERS) fertility and, more generally, of the expected ecosystem services from soils.

Biodiversity indeed contributes to the productivity of agroecosystems and the ecological insurance associated with their stability, resulting both from their resistance to perturbations and their resilience once perturbations have ended. The effect of diversity on ecosystem functioning and stability is essentially illustrated by work on plant communities (Balvanera et al. 2006). The first studies were carried out on grassland systems at Rothamsted (Lawes et al. 1882). Subsequent investigations of plant communities led to the development of a conceptual system relating diversity to ecosystem functioning (Loreau 2000) and demonstrating, in particular, the positive effects of plant diversity on the functioning, performance and stability of agroecosystems (Naeem and Li 1997; Tilman et al. 1996, 1997). These effects are explained in terms of ecological insurance and complementarity of the niches occupied by the component populations of the communities investigated.

Thus, ecological insurance predicts that the risk and amplitude of variations in ecosystem functioning, following a perturbation, will be reduced if the number of species is high (Yachi and Loreau 1999). Each ecosystem function is ensured by a functional group which corresponds to a group of species performing the same function. Under stable environmental conditions, the presence of a minimal number of functional groups is essential to ecosystem functioning but the diversity within each group is of relatively minor importance because the species are redundant from a functional point of view. In contrast, under fluctuating environmental conditions, the presence of a great diversity of species will increase the probability that at least some of them will survive, or even prosper, whatever the conditions and thus ensure the maintenance of system functioning. This is why the level of diversity can be considered as a guarantee of ecosystem stability. This property is of particular importance in the case of agroecosystems regularly subjected to perturbations associated with the mode of land use and climatic variations.

Complementarity between niches but also biotic interactions, such as ecological facilitation and mutualism, are the principal mechanisms proposed to explain the positive link between biodiversity and ecosystem performance. These mechanisms are based on the observation that each species develops within a particular ecological niche; this niche being defined as a function of the requirements of the considered species at physical-chemical, trophic and biological levels, including its relationships with neighbouring species and the resulting modification of the habitat and community to which the species belongs. Different species therefore occupy different habitats and utilize different resources. Thus, an increase of diversity results in better performance (productivity) of the ecosystem due to better occupation of the space by the community and enlargement of the range 
of resources utilized. Furthermore, the decomposition products of one species may also act as a source for another species, thereby increasing niche availability and facilitating interactions.

As in macroorganisms, functional redundancy seems to be a parameter governing the stability (resistance and resilience) of the activities of soil microbial communities after perturbations (Girvan et al. 2005; Griffiths et al. 2000; Griffiths and Philippot 2013). In experiments carried out on grassland systems at Jasper Ridge (California), Horz et al. (2004) demonstrated that modification of the diversity of the nitrating community in soil in response to global changes could lead to an increase in nitrification, thereby illustrating that microbial diversity plays an important role in the nitrogen cycle. Although the mineralization of organic matter is currently considered as redundant, a positive relationship has recently been established between this function and the number of microbial species (Tardy et al. 2014), with mineralization falling significantly when microbial diversity is reduced; similarly, a loss of biodiversity was shown to affect the nitrogen cycle (Philippot et al. 2013b). Such effect of soil biodiversity on mineralization of organic matter directly impacts the release of mineral elements but also the emission of $\mathrm{CO}_{2}$, and therefore soil fertility and environmental quality, respectively.

The relationship between microbial biodiversity and productivity (fertility) was also clearly demonstrated during analyses of plant-microorganisms interactions. Thus, van der Heijden et al. (1998) showed that an increase in the diversity of arbuscular mycorrhizal fungi (AMF) was not only accompanied by an increase in plant diversity, thereby permitting more effective use of light resources at the aerial level and soil resources at the subterranean level, but also improved phosphorus nutrition and finally led to an increase in plant biomass (productivity).

The aim in soil biology research, apart from simply describing its biodiversity, is to determine the relationships between soil diversity and biological function and ultimately the provision of ecosystem services (Fig. 3). For example, the minimal diversity needed for expression of the activities required for a given function, needs to be determined in relation to the functional redundancy. Another research goal is to identify the genes controlling given functions in order to allow the characterization of the corresponding functional communities encompassing different microbial species that have in common these functional genes. Certain of these genes are already known, particularly for the nitrogen cycle (Philippot 2002) and the production of certain antibiotics involved in protection against soil-borne diseases (Weller et al. 2002). However, the proportion of known genes is minimal and numerous genes coding for other activities likely to affect plant growth and health, and, therefore soil fertility, remain to be discovered. The systematic search for these genes will be facilitated by the new high-throughput sequencing techniques and analysis of the metagenome (total genomes) in soil models (Vogel et al. 2009) presenting contrasting levels of fertility (Mougel et al. 2011). At a more general level, determination of the biodiversity-function relationship should lead to identification of pertinent bioindicators of the biodiversity and of the biological functioning of soils in relation to the expected ecosystem services. This relationship is currently being investigated in long-term observatories allowing to characterize together soil biodiversity, fertility and ecosystem services.

\subsection{Bioindicators}

Numerous molecular tools have been developed over the past 20 years which today allow the routine characterization of microbial communities at both quantitative and qualitative levels (Maron et al. 2011).

The total microbial communities and communities determining a particular function or belonging to taxonomic groups of particular interest or presenting a danger can therefore be quantified. The abundance of total microbial communities can be measured from the microbial molecular biomass (Dequiedt et al. 2011). The microbial biomass is a well-known marker of soil biological functioning (Horwath and Paul 1994) and a sensitive and early indicator of changes in soil management (farming practices, contamination; Ranjard et al. 2006). The molecular biomass is determined by quantifying the microbial DNA in soil extracts and is correlated with the microbial biomass (Marstorp et al. 2000; Leckie et al. 2004) measured after fumigation-extraction (Vance et al. 1987), although this relation may vary according to the soil type and more specifically to their carbon content (Leckie et al. 2004). The advantage of molecular biomass, compared with the biomass obtained after fumigation-extraction, is that it can be measured on dry soil samples at the same time as physical-chemical analyses and that it allows the development and application of referential systems, using a moderate-throughput system, for interpreting analysis data (cf. Section 2.4).

Functional communities, or those belonging to a particular taxonomic group, can also be quantified from soil DNA extracts by applying quantitative polymerase chain reaction (PCR used to amplify DNA) to determine the number of copies of the functional gene shared by populations in the functional community or of a specific sequence in the targeted taxonomic group. One example of functional community concerns bacteria with the ability to synthesize the antibiotic 2,4-diacetyphloroglucinol (Mavrodi et al. 2007). The level of natural suppressiveness of soils to take-all, caused by Gaeumannomyces graminis var. tritici, has been associated with the density of bacteria harbouring sequences encoding the synthesis of corresponding antibiotic (Raaijmakers et al. 1997). The copy number of this sequence could therefore be an indicator candidate for assessing of the risk of disease expression. The presence and abundance of particular 
microbial groups including beneficial microorganisms, such as symbiots (cf. Section 3.1), or deleterious organisms representing health risks, for animals, humans or plants, may also be quantified using taxonomic marker genes (Redecker and Raab 2006).

From a qualitative point of view, the composition of communities can be characterized by their structure, i.e. assemblage of the different constitutive populations, and by their diversity, i.e. the different types of organisms present. The genetic structure may be determined by molecular fingerprints of the communities. Until recently, comparisons between studies were hampered by the great variety of techniques employed (A-RISA, ARDRA, DGGE, TGGE, T-RFLP...), and some sort of standardization was clearly necessary. This was undertaken by national and European programmes (Gardi et al. 2009), such as those conducted in the UK (Countryside Survey, www.countrysidesurvey.org.uk) and in Europe (EcoFINDERS, http://www.ecofinders.eu/, Lemanceau 2011) which use the terminal-restriction fragment length polymorphism (T-RFLP) technique and that conducted on the French soil survey (Réseau de Mesure de la Qualité des Sols, RMQS) (http://www.gissol.fr/programme/rmqs/rmqs. php) which uses the automated ribosomal intergenic spacer analysis (A-RISA) technique. Due to the progress achieved with new high-throughput sequencing technologies and their highly significant reduction in cost, the diversity of microbial communities can now be compared in contrasted situations of soil type, climate and land use. Analyses of the relationships between soil diversity, fertility and delivered ecosystem services provide opportunities for identifying new bioindicators.

\subsection{Need for standardized referential systems}

Once sensitive, reliable and easy-to-use bioindicators have been developed, it is essential to know their range of variation in order to interpret the measured values and diagnose the biological state of a soil.

This requires prior research to evaluate the impact of different environmental situations on (1) the abundance and diversity of the microbial communities and (2) the activities of those communities, soil biological functioning and the ecosystem services provided. The environmental filters affecting microbial communities and their activities therefore have to be identified. Thus, to take into account the effect of environmental conditions on microbial communities and their functioning, long-term studies are set up on sites especially equipped to measure soil biological functioning and the ecosystem services of interest, and to determine their relationship with soil biodiversity. This type of approach is being applied by the European programme EcoFINDERS in which several long-term observatories have been identified in Europe as representative of types of climate and land use.
From an operational point of view, the interpretation of the soil biological analyses requires referential systems which indicate the normal range of variations of the bioindicators (abundance, microbial composition) according to the type of soil, climate and land use. Standardization of the procedures is paramount for construction of these referential systems and their application to soil biological analyses. Major progress has been achieved in this field during the last few years by national programmes in France (Bispo et al. 2009, programme ADEME Bioindicateur, http://ecobiosoil.univ-rennes1.fr/ ADEME-Bioindicateur/; Dequiedt et al. 2011; Peres et al. 2011; Ranjard et al. 2010), in the Netherlands (The Biological Indicator system for Soil Quality, Rutgers et al. 2009), in the UK (Griffiths et al. 2011), and, more recently, in Europe (projects ENVASSO http://www.envasso.com/, EcoFINDERS). All these programmes aim at analysing soil communities, especially microbial, on very large spatial scales. Such large-scale analyses require massive sampling efforts, which in France, for example, are carried out by the RMQS managed by Groupement d'Intérêt Scientifique (GIS) Sol (http://www.gissol.fr/index.php) and operational structures to extract the DNA from these extremely numerous samples, then manage, store and analyse them (platform GenoSol http://www2.dijon.inra.fr/plateforme genosol/, Ranjard et al. 2009).

The soil sampling strategy used for microbial analyses in France and Europe (project EcoFINDERS) consists of harvesting several samples, the number (three on average) depending on the heterogeneity of the plot to be analysed. Each of these samples is obtained by mixing five sub-samples of $500 \mathrm{~g}$ taken (by drill) from the top $20 \mathrm{~cm}$ of the soil. Each bulk sample is then sieved and homogenized, and reduced in mass to $100 \mathrm{~g}$ by quartering in order to facilitate storage (Fig. 4; Plassart et al., personal communication). The extraction of DNA is carried out on sub-samples of $1 \mathrm{~g}$ for bacteria and $5 \mathrm{~g}$ for fungi. These values were previously determined from studies to measure the minimal soil mass beyond which the diversity no longer increases (Ranjard et al. 2003).

Similarly, an effort has been made to standardize the soil DNA extraction procedure by adopting an ISO standard (ISO Standard 11063 2009; Philippot et al. 2010; Petric et al. 2011). This procedure has recently been optimized to ensure good amplification of the DNA not only from bacterial communities but also fungi and archaea (Plassart et al. 2012).

The distribution of microbial communities, in terms of abundance, is heterogeneous but structured on different spatial scales. Parameters contributing to this structuring are (1) on a microscale - the structure, porosity and organic carbon content of the soil (Ranjard and Richaume 2001); (2) on the scale of a farm plot - the texture (Johnson et al. 2003; Lejon et al. 2007), pH (Bååth and Anderson 2003), organic matter content (Lejon et al. 2007), land use (Nicolardot et al. 2007) and plant cover (Lejon et al. 2005); and (3) on larger scales (landscape, 
a Soil sampling

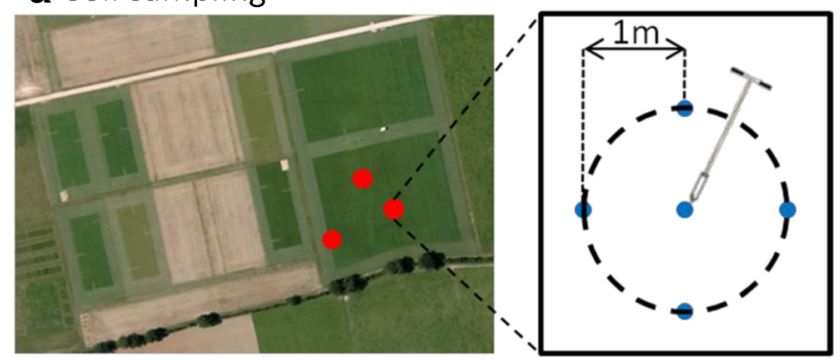

b Soil homogenization

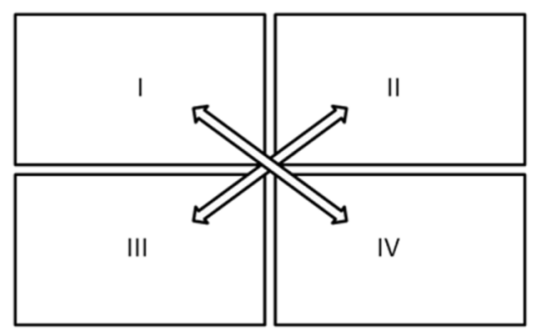

c Soil storage

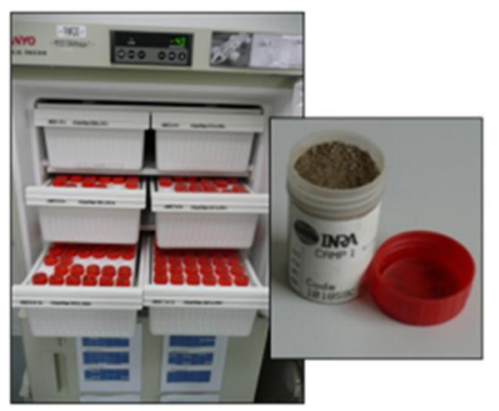

Fig. 4 Sampling strategy for soil microbiogical analyses (from Plassart et al., unpublished data): three soil samples are collected (red dots) per analysed plot, each sample results from five pooled sub-samples (blue dots) (a); such soils samples are sieved and homogenized by quartering (b); samples are finally aliquoted $(100 \mathrm{~g})$ and stored at $-40{ }^{\circ} \mathrm{C}$ (c)

country) - the physical-chemical properties and land use (Dequiedt et al. 2011). Thus, on the scale of France, the molecular biomass, which represents the microbial abundance (Section 2.3), varies from 5 to $15 \mu \mathrm{g}$ of DNA per gram depending on the soil (Fig. 5). These variations are associated with the major soil types and in particular their physicalchemical properties and land use. Thus, the molecular biomass values are positively linked to the clay and $\mathrm{Ca}$ contents, $\mathrm{pH}$ value and cation exchange capacity of soils (Dequiedt et al. 2011). The mean molecular biomass values are highest in grassland and lowest in orchards and vineyards (Fig. 6). This latter observation may be linked to the very poor plant diversity observed in orchards and vineyards due to perennial culture of the same plant genotypes and the frequent absence of grass between the rows in these crops. More generally, it is clearly apparent from reference values obtained at a national level that measurements of molecular biomass must be interpreted with regard to the normal range of variations for a given soil type and mode of land use (Figs. 5 and 6).

The analyses performed on soil samples obtained from the RMQS indicate that, like their abundance, the genetic structure of communities based on A-RISA fingerprinting is also heterogeneous but spatially structured (Dequiedt et al. 2009). This distribution is again affected by soil type (physicalchemical characteristics, especially $\mathrm{pH}$ ) and land use, especially the degree of intensification. The major influence of $\mathrm{pH}$ on the structure and diversity of microbial communities was also demonstrated during analogous studies in the UK (Griffiths et al. 2011) and USA (Fierer and Jackson 2006; Jones et al. 2009).

\section{Ecological engineering}

Diagnosis of a soil's biological state must obviously be accompanied by recommendations to improve, maintain or even restore fertility as well as the associated ecosystem services. Two types of ecological engineering strategies can be used. The first relatively classical approach consists of inoculating plants with strains selected for their beneficial activities, whereas the aim in the second approach, which is more ambitious and more complex, is to orient the indigenous microbial communities by adapting the farming system.

Both strategies rely strongly on the management of the interactions occurring between plants and soil microorganisms in the rhizosphere. In fact, these microorganisms are mostly heterotrophic and therefore rely on the primary production provided by plants which are autotrophic. During plant development, a significant proportion of photosynthates $(\approx 20 \%)$ is released in the form of rhizodeposits (Nguyen 2003 ) and, at the end of its development cycle, the plant organic compounds are returned to the soil. The plant selects from the soil microflora those populations best adapted to the rhizosphere environment and these will differ according to the plant genotype (Manter et al. 2010). Maintenance of the release of rhizodeposits during plant evolution and its general occurrence throughout the plant kingdom suggests that the corresponding cost is compensated by benefits for the plant (for review, see Lambert et al. 2009). Thus, the microbial populations selected by the plant in its rhizosphere would be beneficial to its growth and health, and thus facilitate its adaptation in situations of low fertility (e.g. AMF and nitrogen-fixing bacteria; Section 3.1) and/or of high densities of pathogenic populations. The decline of take-all in wheat has thus been attributed to the selection, by roots infected with the pathogenic agent, of bacterial populations producing antibiotics (Section 2.2), which may probably have helped to maintain this plant species overtime (Cook et al. 1995). Generally speaking, the maintenance of plant species in 
Fig. 5 Variations in microbial molecular biomass on the scale of France based on observations obtained by the French Network for the Measurement of Soil Quality "Réseau de Mesure de la Qualité des Sols" (http://www. gissol.fr/programme/rmqs/rmqs. php). The variations of microbial biomass are represented by a range of colours from brown shades, corresponding to soils with a high molecular biomass

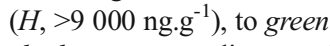
shades, corresponding to soils with a low molecular biomass $\left(L,<7000\right.$ ng. $\mathrm{g}^{-1}$ ) (Dequiedt et al. 2011)

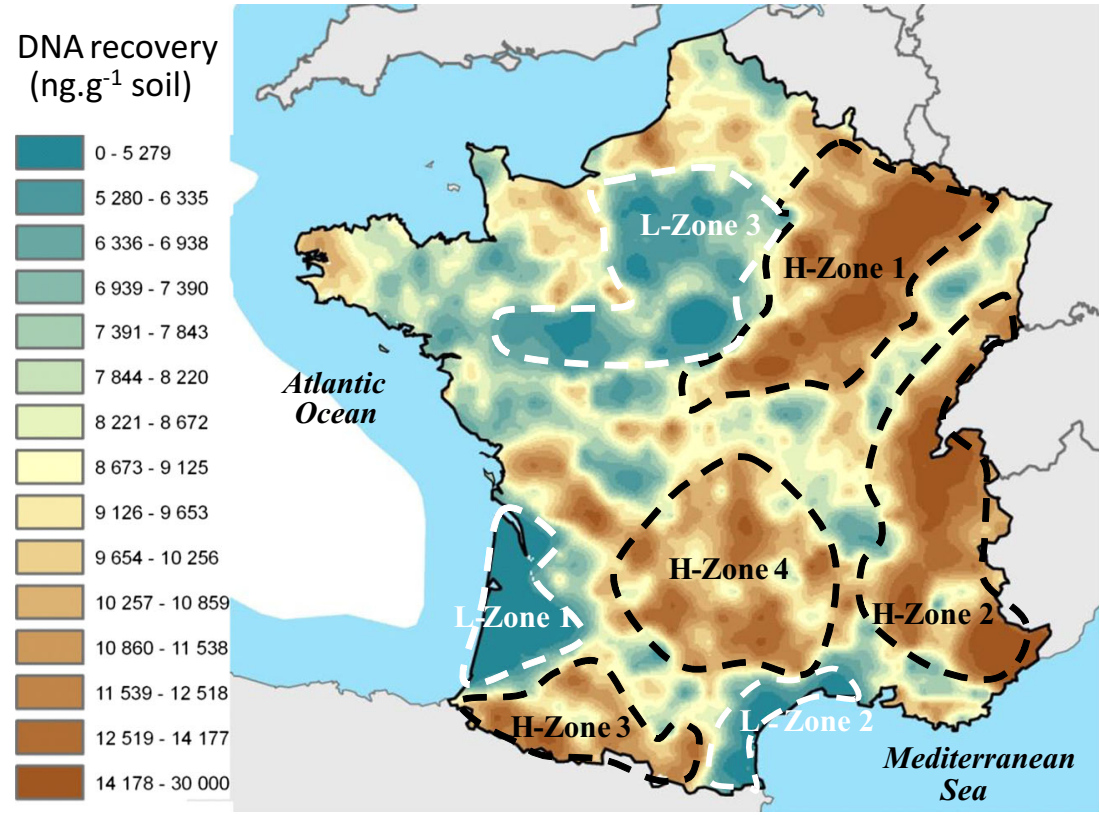

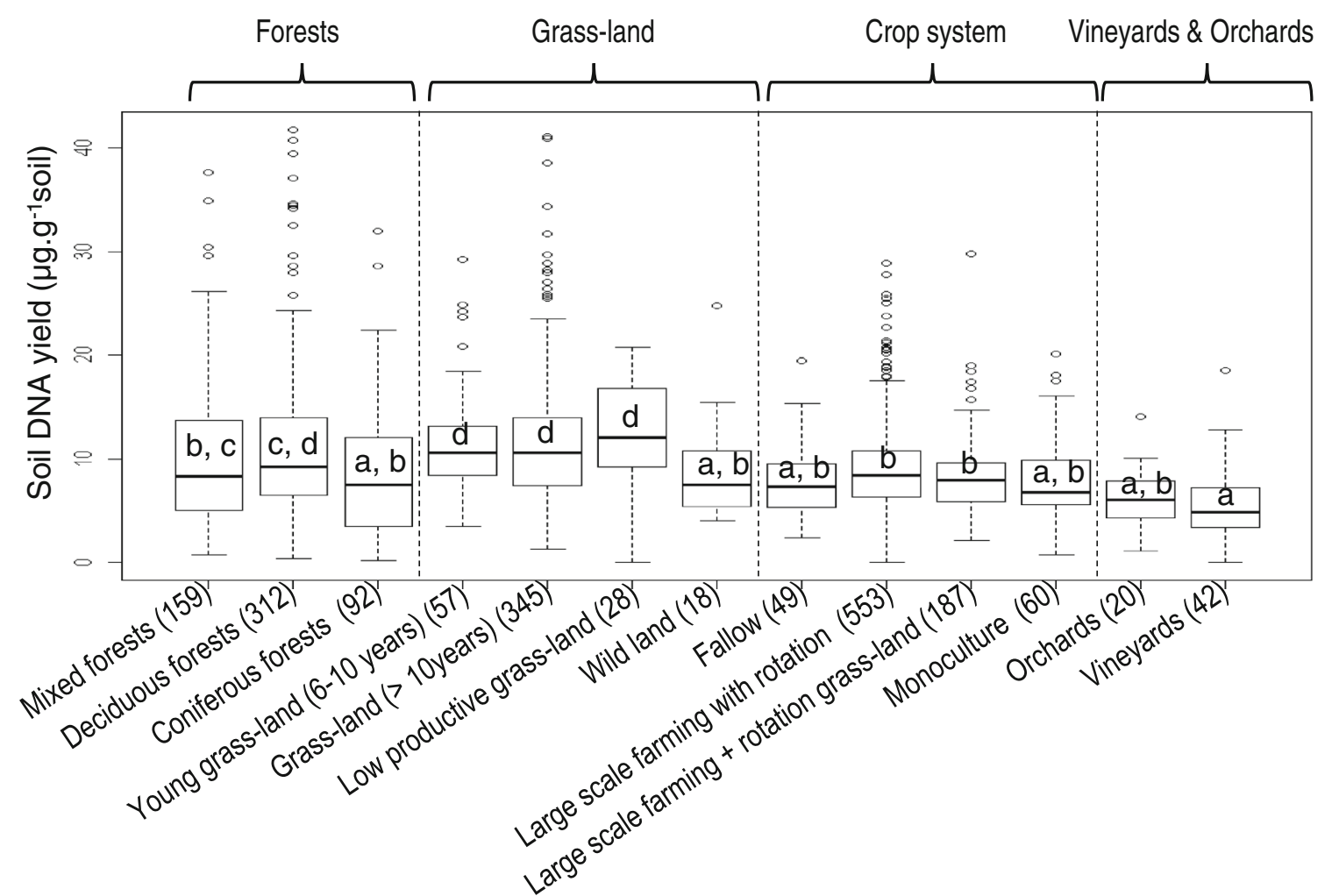

Fig. 6 Mean values and ranges of variations of the microbial molecular biomass on the scale of France according to land use, based on observations obtained by the French Network for the Measurement of Soil Quality (Réseau de Mesure de la Qualité des Sols; http://www.gissol.fr/ programme/rmqs/rmqs.php). The numbers between brackets indicate the number of sites sampled for the corresponding types of land use; the letters indicate the significant differences between different types of land use $(P>0.05)$ and the standard deviations indicate the ranges of variations per type of land use (Dequiedt et al. 2011). The mean and range of variations of microbial molecular biomass vary according to the land use, the lowest mean value being found in land uses with the lowest plant diversity (orchards, vineyards) and the highest in land uses with the highest plant diversity (grass-lands) 
poorly anthropized situations seems to have relied on coevolutionary processes in plants and microorganisms which involve reciprocal benefits. Some of these processes are very ancient, for example 60 million years for symbioses with nitrogen-fixing bacteria (Sprent 2008) and 450 million years for endomycorrhizal symbioses (Redecker et al. 2000).

\subsection{Microbial inoculation}

Two main examples are described concerning the introduction of selected strains of microorganisms which establish symbiotic associations with the plant-host.

The first example is the symbiotic association between Rhizobia and leguminous plants. This reciprocally beneficial association provides the bacteria with the carbon resources necessary for growth and the bacteria assist the plant by fixing the atmospheric nitrogen essential to its development. For a long time (until the beginning of the twentieth century), this biological fixation of atmospheric nitrogen was the only way that nitrogen compounds could enter the soil, and, on a world scale, even today ensures a greater supply than fertilisers. The estimated amount is 122 million tons per year (Herridge et al. 2008), half of which is fixed by the Rhizobia-leguminous symbiosis (Werner and Newton 2005; Lindstrom et al. 2010). Although the beneficial effect of leguminous plants on soil fertility has been known since antiquity, the first agronomic applications date from the beginning of the twentieth century. As soon as it became possible to cultivate Rhizobia, these nitrogen-fixing symbiotic bacteria were added to the seeds of leguminous plants at the time of sowing. This represents the most ancient application of bacteria in agriculture. It has been used ever since throughout the world and has become a common agricultural practice. Different crops are inoculated, including fodder crops such as alfalfa and clover, and grain legumes such as peas, beans and soybean. Each year, millions of hectares throughout the world have been and are currently inoculated with different species of Rhizobia (Catroux et al. 2001). Thus, the inoculation of soybean (Fig. 7), a legume originating from the Far East, has extended cultivation of this species to soils devoided of the corresponding symbiotic bacteria (Bradyrhizobium japonicum) throughout the world in less than 50 years; this crop now covers more than 100 million hectares (Lindstrom et al. 2010). Work has recently been carried out to explore the feasibility of inoculating strains of Rhizobium which not only fix atmospheric nitrogen during symbiosis with leguminous crops but also reduce $\mathrm{N}_{2} \mathrm{O}$ to $\mathrm{N}_{2}$, and thus help to reduce emission of this greenhouse gas (Henault and Revellin 2011). Trials under controlled conditions have shown that $\mathrm{N}_{2} \mathrm{O}$ emissions can be decreased by inoculating soybean with the strain $B$. japonicum G49, which possesses the ability to reduce $\mathrm{N}_{2} \mathrm{O}$ to $\mathrm{N}_{2}$. This property has also been demonstrated in the strain Sinorhizobium meliloti 2011 in symbiosis with alfalfa.

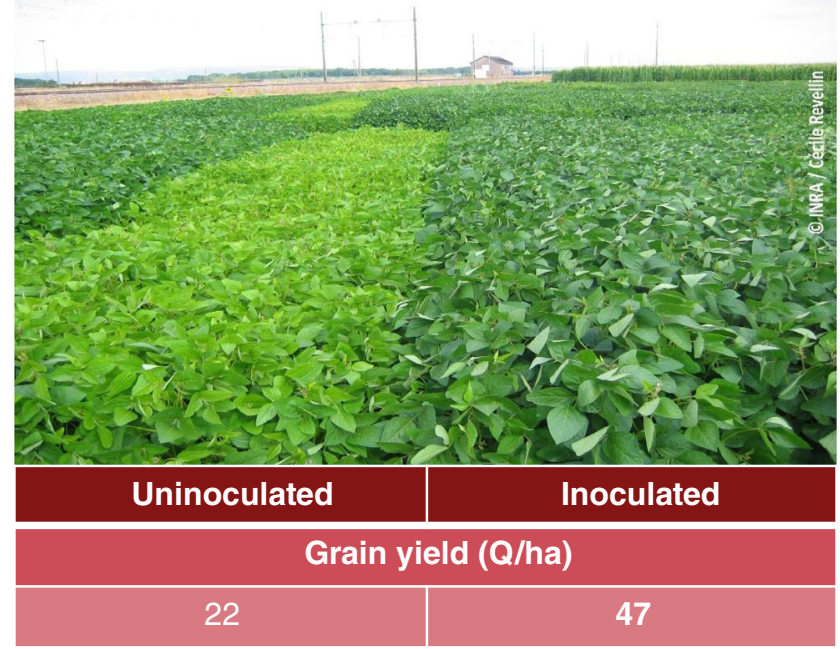

Fig. 7 Example of yield promotion of soybean when inoculated with Bradyrhizobium japonicum. Bacterial symbiosis leads to a better nitrogen nutrition of the host-plant and therefore to a better growth and grain yield

Application of this property is currently being assessed under field conditions.

The second example is the symbiotic mycorrhizal symbiosis which likely appeared more than 450 million years ago (Redecker et al. 2000) and made it possible for the first plants to colonize land. Mycorrhizal associations have proved so necessary and beneficial that, over the past 300 million years, the great majority of higher plants have conserved this symbiotic system and both partners have co-evolved together. It is rare to find a non-mycorrhized plant in nature or even in cultivated plants (with the exception of Brassicaceae and Chenopodiaceae). Arbuscular mycorrhiza are present in most cultivated plants (agricultural and horticultural), ranging from aromatic plants to fruit trees and including cereals. The hyphae of AMF colonize the plant's roots and are able to explore a volume of soil that is 1000 times greater than that explored by the roots alone (Smith and Read 2008). They create specific structures known as arbuscules which allow the transfer of water and nutrients between both partners (Fig. 1d). AMF thus play the role of biofacilitators, improving plant nutrition and resistance to biotic stresses such as water deficit (Gianinazzi et al. 2010). They also influence plant development and the quality of plant products and in this way act as bioregulators. In return, the fungus benefits from photosynthates (up to $20 \%$ ) produced by the plant in the form of carbon compounds (Smith and Read 2008). Although the principal advantage conferred by the mycorrhiza is trophic in nature, non-nutritional effects are also observed. Thus, mycorrhizal fungi (MF) act as bioprotectors by reinforcing the natural defences of the plant against soil pathogens (Gianinazzi et al. 2010). In addition, the mycelial network encourages better retention of the aggregates and stabilization of the soil structure, thus contributing to soil quality. For several years, research has demonstrated the interest of using mycorrhizal 
cultures to reduce chemical inputs, as well illustrated with horticultural and vegetable soilless crops, so long as the cultural practices applied are compatible with the development and beneficial expression of mycorrhizal symbioses (Gianinazzi et al. 2010). The interest of inoculating selected strains of AMF has thus been demonstrated for numerous crops such as onion, corn, clover, leek, artichoke, sweet potato, asparagus, olive, apple, pear, grape vine, raspberry, strawberry, rose, liquidambar, Virginia creeper, catalpa and lilac (for review, see Gianinazzi et al. 2010). Recently, the use of mycorrhiza to improve the quality of agricultural products by their enrichment with compounds beneficial to health and taste, such as sulphur molecules (onion), carotenoids (sweet potato), essential oils (basil) or oligoelements (lettuce) has been reported (Baslam et al. 2011; Copetta et al. 2006; Gianinazzi et al. 2010). For the past 50 years, valorisation of indigenous populations of MF has been hindered by the reduction and simplification of crop rotations, the use of synthetic inputs and the cultivation of new plant genotypes. Possible application of inoculation strategy in open field crops is also strongly hindered by inoculant available on the market at prices compatible with the economic activity. Indeed, production of inocula is particularly difficult and therefore expansive since MF are obligatory symbionts and require the help of a host-plant for their multiplication. Nevertheless, in recent years, systems used to produce inocula have evolved considerably, passing from direct production on nursery plots for uses in situ, to production in containers in glasshouses and more recently to tanks in vitro for large-scale usage.

Other applications of microbial inoculation have been tested using mutualistic microorganisms to improve soil fertility; however, the results obtained are poorly reproducible due to the frequent absence of persistence of the inoculum in soils. This is associated with the presence of indigenous microorganisms in the soil which are better adapted to the biotic and abiotic environment than the introduced strain.

\subsection{Orienting the microbial populations/communities}

In the light of these findings, a change of paradigm has been proposed. This consists of no longer introducing selected strains but instead making use of indigenous populations by promoting among microbial communities those favourable to plant growth and health through the adoption of suitably adapted farming practices. Again, these agricultural practices are essentially based on managing the primary products of plants, whether these are released during the plant life cycle as rhizodeposits, or after as crop residues.

Soil functioning as a nutrient bank The soil organic matter (SOM) derived from plant development contains very large amounts of nutrients (nitrogen, phosphorus) representing, for example, 30 to 100 times the annual uptake of nitrogen from a permanent grassland or a forest. These nutrients may be sequestered within the SOM for several decades, even centuries, before being released by microbial decomposition. Therefore, most of this organic stock of nutrients is not available to plants which are only able to absorb soluble forms. However, the microbial communities of decomposers (essentially fungi) are able to mineralize this recalcitrant SOM (Fontaine et al. 2011; Fig. 8). Thus, in ecosystems with low anthropogenic pressure, soils function as a nutrient bank with microbial communities contributing to the formation of organic reserves, when nutrient availability in the soil solution is high, and to the mineralisation of these reserves, when the soil solution is nutrient-deficient, thereby ensuring the mineral nutrition of plants. However, this mineralization is accompanied by the emission of $\mathrm{CO}_{2}$, a greenhouse gas. These observations could be applied to cultivated soils to find cropping systems, which are able to modulate the amplitude of the variations in SOM storage/mineralization, as for example those involving a continuous plant cover of soils. In this way, the release of nutrients from SOM would be adapted to the plant's requirements, thereby maximizing its production potential and at the same time minimizing $\mathrm{CO}_{2}$ emission and $\mathrm{N}$ losses by leaching or denitrification.

Repression of nitrification Another example concerns the nitrogen cycle and more especially the nitrification, which is one of the main microbial processes responsible for nitrogen losses from terrestrial ecosystems. During this process, ammonium, which is relatively stable in soils, is oxidized to nitrate - a very mobile form of nitrogen. Thus, nitrate cannot only be transformed into gaseous nitrogen by denitrification but can also be readily lost due to leaching. This not only implies losses in terms of fertility but also adverse effects on the environment. An elegant series of experiments performed over the past 10 years has demonstrated a new way of limiting mineral nitrogen losses due to nitrification via the host-plant. Lata et al. $(2000,2004)$ demonstrated an inhibitory effect of Hyparrhenia diplandra on nitrification which resulted from simple competition between plants and nitrifying microorganisms for ammonium. This inhibition was associated with presence, in the root exudates, of molecules such as brachialactone which specifically inhibit two enzymes (ammonia monooxygenase and hydroxylamine oxidoreductase) involved in the oxidation of ammonium to nitrite, during the first step of the nitrification process (Subbarao et al. 2009). Field assessment for 3 years of plants exhibiting high production of these inhibitory molecules revealed a reduction of nitrification of up to $90 \%$ together with considerable reduction of the number of nitrifying microorganisms (Subbarao et al. 2009). Research is currently underway to introduce this trait into cultivated plants, which might not only reduce the losses of mineral nitrogen but also limit emissions of the greenhouse gas $\mathrm{N}_{2} \mathrm{O}$ by denitrification (Philippot and Hallin 2011). 
Nutrient-releasing soil (a)

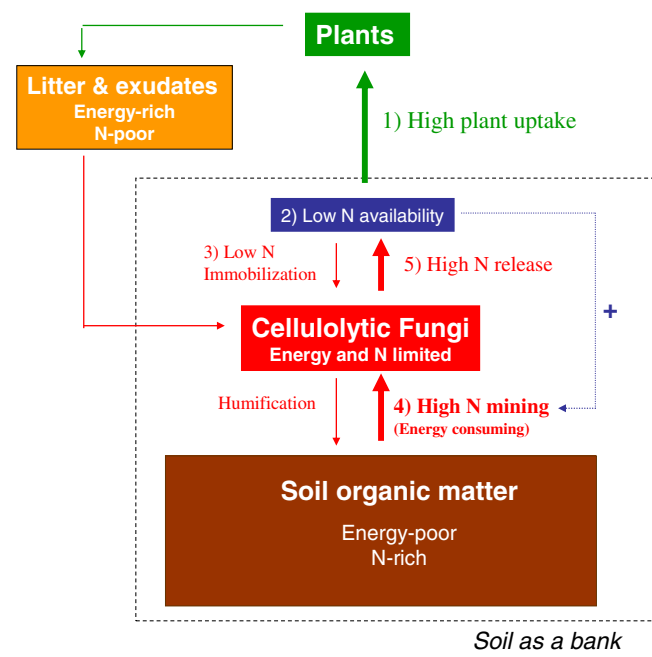

Fig. 8 Diagrammatic representation of the activity of the fungal decomposer community according to the level of nitrogen requirements of the plant. When requirements are high (a), the mineral concentration in the soil solution falls leading to mineralization of the soil organic matter (rich in nitrogen and poor in energy); this situation leads to a release of

\section{Research for plant genotypes promoting microbial communi-} ties beneficial to plant growth and health Over the past decades, plant breeding programmes have produced highperforming cultivars and significantly contributed to the increased yields and technological quality of agricultural products. This has occurred at the same time as the increased use of synthetic inputs to optimize expression of the genetic potential of selected cultivars. This approach is based on a general strategy which consists in adapting the environment to the crop, with soilless crops as extremes. In contrast, the proposed change of paradigm in agroecology consists of adapting the crop to the environment, by searching for plant genotypes which require less inputs and optimize better the soil resources specially by selecting within the soilborne microbiome populations that are beneficial for their growth and health (Fig. 9). Obtaining these genotypes first requires identification of the genetic and ecophysiological traits of the plant that are involved in selecting these favourable microbial populations (Friesen et al. 2011). Several strategies have been proposed to attain this objective. The first is a genetic association approach involving cultivation of numerous plant genotypes in a given soil. The possible variations in development of these genotypes are assumed to be at least partly associated with the variations in composition of the microbial community in the rhizosphere. The populations specifically identified in the rhizosphere of genotypes exhibiting the best growth are then tested for their aptitude to promote the growth/health of the hostplant (Zancarini et al. 2013a, b). Corresponding research on the model plant Medicago truncatula is underway (Zancarini et al. 2013a, b).
Nutrient-sequestering soil (b)

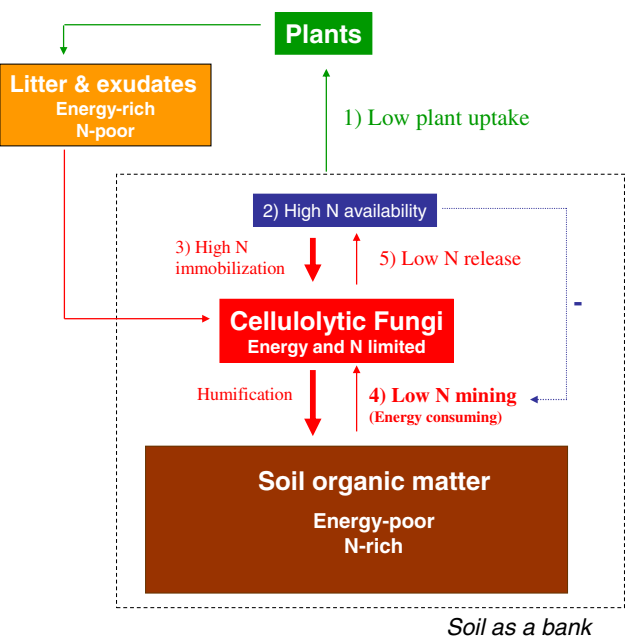

nutrients to the plant but also an emission of $\mathrm{CO}_{2}$ and de-stocking of the soil carbon. When requirements are low (b), the fresh organic matter (energy-rich and nitrogen-poor) is transformed by the fungal community of decomposers into soil organic matter (humification) contributing to carbon storage in the soil (Fontaine et al. 2011)

The second strategy is based on comparison of the microbial communities associated with a wild plant genotype (WT) and with a series of mutants of that genotype all cultivated in the same soil. The mutants presenting poorer growth/health than WT are identified and their microbial communities are compared with those of WT. The populations present in the rhizosphere of WT, but not in that of the mutants, are considered as possible candidates for explaining the better growth and health of WT. If this effect is confirmed in complementary trials in which WT genotype is cultivated in gnotobiotic conditions in the presence of those candidates, the WT genotype is then compared with that of the mutants, to identify the candidate genetic traits involved in selection of the corresponding beneficial populations.

Finally, recent research conducted on Arabidopsis thaliana has led to the concept of a principal rhizosphere microbiome, corresponding to the endophytic microbial populations found in the host-plant irrespective of the type of soil and physiological state of the plant (Bulgarelli et al. 2012; Lundberg et al. 2012). The authors put forward the hypothesis that the corresponding microbial groups would consist of favourable microbial populations, but again this hypothesis needs to be tested in complementary trials.

In each of the proposed approaches, the composition of the microbial community is characterized by high-throughput sequencing. All these studies require complementary expertise in microbial ecology, plant ecophysiology and genetics, and should eventually result in the development of new strategies for the genetic selection of cultivated plants which are not only productive but also more thrifty with regard to input requirements and which best valorise the regulations and interactions between organisms (Zancarini et al. 2013b). 


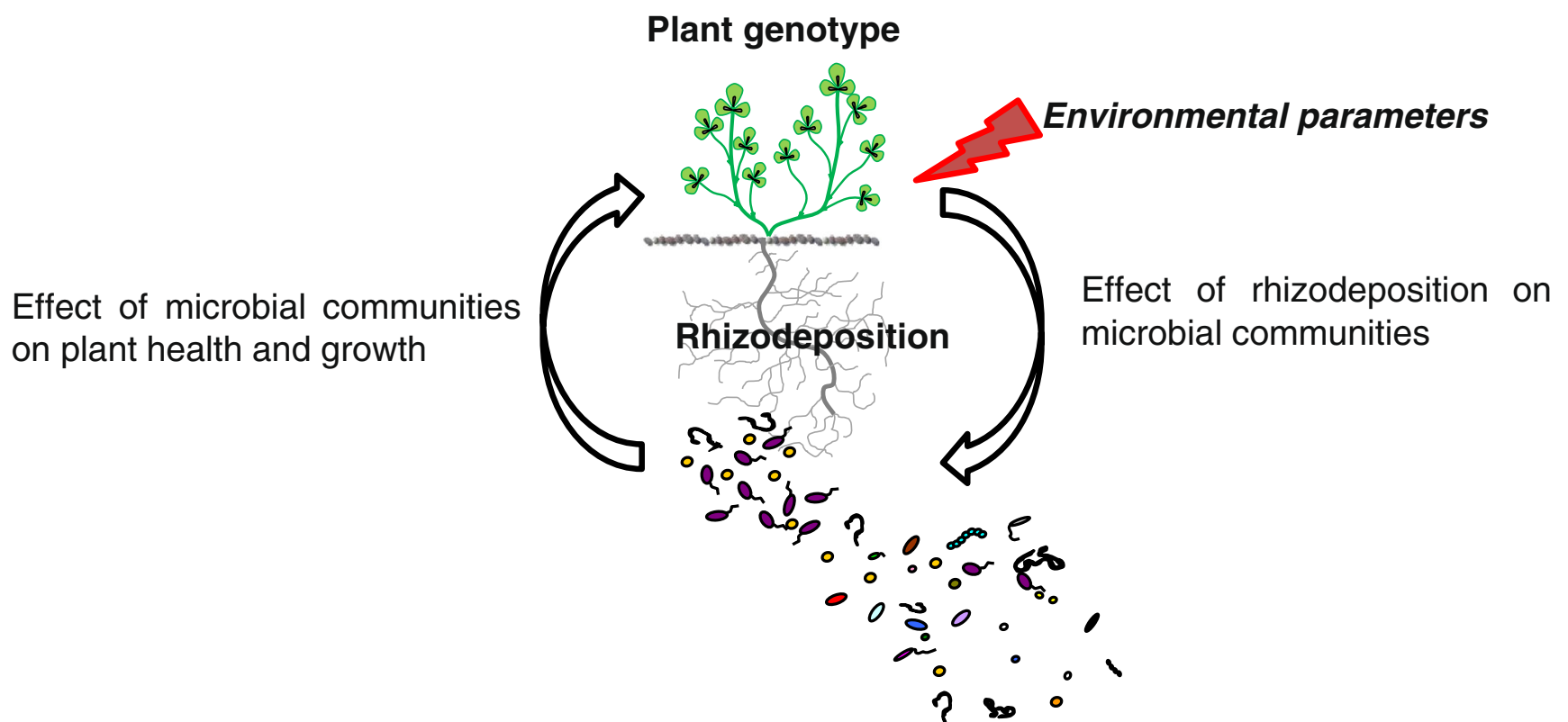

Fig. 9 Diagrammatic representation of the relationships between plant genotype and soil microbial communities. Rhizodeposition varies according to the plant genotypes and environmental conditions. Resulting variations of rhizodeposition impact microbial communities (abundance,

\section{Conclusions and prospects}

Research in soil microbial ecology has progressed considerably during the last two decades, and procedures can now be proposed to diagnose the biological state of soils in relation to their fertility. This diagnosis is based on (1) analysis of the abundance and composition of the microbial communities, and of specific bioindicators and (2) interpretation of the corresponding analyses by comparing them with reference values representing the normal range of variations for the parameters analysed. These reference values are obtained from large-scale analyses carried out on national, European and even continental scales with the support of global initiatives such as the Global Soil Biodiversity Intiative (http://globalsoilbiodiversity.org/) and the Global Soil Partnership (http://www.fao.org/ globalsoilpartnership/). Progress has been assisted by the development of specialized structures and platforms. Research is underway to determine the relationships between diversity and biological functions in different environmental situations so that new bioindicators of soil biological state can be developed and the corresponding range of variations specified.

Several standardized procedures also exist for characterization of the soil fauna. These procedures are based on the extraction of each type of organism and their description, which is essentially based on morphological characters. One possible improvement, as with the characterization of microbial communities, would be to extract the DNA rather than the soil organisms, then amplify specific sequences and finally study their polymorphism (Orgiazzi et al., submitted). This approach would obviously depend on the specification of diversity, activity) in the rhizosphere. In return, modifications of microbial communities impact plant growth and health and consequently rhizodeposition. These reciprocal interactions therefore correspond to a feedback loop

appropriate soil sampling procedures, extraction of the DNA from very large volumes of soil and definition of the specific targeted sequences (Orgiazzi et al., submitted).

Ecological engineering research, based on diagnosis of the biological state of soils, is faced with the major challenge of proposing decision-making aids so that recommendations can be formulated, as routinely done on the basis of physicalchemical analyses. Such research lies in the field of agroecology where the aim is to valorise biodiversity and regulations among organisms and communities. In the case of soil biology, two principal approaches can be considered.

The first consists of the introduction of microbial strains selected for their beneficial effects. This approach is used in large-scale applications especially to inoculate soybean with Bradyrhizobium. Where non-symbiotic bacteria are concerned, however, such applications are greatly hampered by the lack of reproducibility of the beneficial effects. This might be improved by searching for compatible plant genotypemicrobial genotype associations which would ensure better survival of the inoculum (Smith et al. 1999). Similarly, the large-scale production of AMF could be optimized together with the conditions of plant inoculation in relation to the evolution of culturing systems (inoculation of plug-plants).

The aim in the second approach is to reconsider the cropping systems so as to favour the microbial populations and activities beneficial to plant growth and health, and, at the same time, reduce adverse environmental effects. This will require the development of plant genotypes which valorise the biotic resources of soils and select beneficial communities within their rhizosphere. The challenges are particularly great 
as regards the significant, but under-exploited, proportion of photosynthates devoted to rhizodeposits (Philippot et al. 2013a). The general goal is to integrate into the very conception of farming systems, an awareness of the influence of husbandry techniques (e.g. crop rotations, crop associations, intercropping, cover crops, crop residue management) on microbial abundance, diversity and activity. One way is to increase the use of leguminous crops so as to get maximum benefit from the entry of nitrogen into soils via biological fixation.

Acknowledgments This work was supported by the European Commission within the EcoFINDERS project (FP7-264465). The authors are grateful to Diana Warwick for helping with the English text and to Laure Avoscan and Annie Colombet for photos of microscopic observations.

\section{References}

Bååth E, Anderson TH (2003) Comparisons of soil fungal/bacterial ratios in a $\mathrm{pH}$ gradient using physiological and PLFA-based techniques. Soil Biol Biochem 35:955-963. doi:10.1016/S0038-0717(03) 00154-8

Balvanera P, Pfisterer AB, Buchmann N, He JS, Nakashizuka T, Raffaelli D, Schmid B (2006) Quantifying the evidence for biodiversity effects on ecosystem functioning and services. Ecol Lett 9:11461156. doi:10.1111/j.1461-0248.2006.00963.x

Baslam M, Pascual L, Sanchez-Dial M, Erro J, Garcia-Mina JM, Goicoechea N (2011) Improvement of nutritional quality of greenhouse-grown lettuce by arbuscular mycorrhizal fungi is conditioned by the source of phosphorus nutrition. J Agric Food Chem 59:11129-11140. doi:10.1021/jf202445y

Bates ST, Berg-Lyons D, Caporaso JG, Walters WA, Knight R, Fierer N (2011) Examining the global distribution of dominant archaeal populations in soil. ISME J 5:908-917. doi:10.1038/ismej.2010.171

Bispo A, Grand C, Galsomies L (2009) Le programme ADEME "Bioindicateurs de qualité des sols". Étude Gest Sols 16:145-158

Bulgarelli D, Rott M, Schlaeppi K, van Themaat EVL, Ahmadinejad N, Assenza F, Rauf P, Huettel B, Reinhardt R, Schmelzer E, Peplies J, Gloeckner FO, Amann R, Eickhorst T, Schulze-Lefert P (2012) Revealing structure and assembly cues for Arabidopsis root inhabiting bacterial microbiota. Nature 488:91-95. doi:10.1038/ nature 11336

Catroux G, Hartmann A, Revellin C (2001) Trends in rhizobial inoculant production and use. Plant Soil 230:21-30

Cook RJ, Thomashow LS, Weller DM, Fujimoto D, Mazzola M, Bangera G, Kim D (1995) Molecular mechanisms of defense by rhizobacteria against root disease. Proc Natl Acad Sci U S A 92:4197-4201

Copetta A, Lingua G, Berta G (2006) Effects of three AM fungi on growth, distribution of glandular hairs, and essential oil production in Ocimum basilicum L. var. Genovese. Mycorrhiza 16:485-494. doi:10.1007/s00572-006-0065-6

Dequiedt S, Thioulouse J, Jolivet C, Saby NPA, Lelievre M, Maron PA, Martin MP, Chemidlin-Prévost-Bouré N, Toutain B, Arrouays D, Lemanceau P, Ranjard L (2009) Biogeographical patterns of soil bacterial communities. Environ Microbiol Rep 1:251-255. doi:10. 1111/j.1758-2229.2009.00040.x

Dequiedt S, Saby NPA, Lelievre M, Jolivet C, Thioulouse J, Toutain B, Arrouays D, Bispo A, Lemanceau P, Ranjard L (2011) Biogeographical patterns of soil molecular microbial biomass as influenced by soil characteristics and management. Glob Ecol Biogeogr 20:641-652. doi:10.1111/j.1466-8238.2010.00628.x
Fierer N, Jackson RB (2006) The diversity and biogeography of soil bacterial communities. Proc Natl Acad Sci U S A 103:626-631. doi: 10.1073/pnas.0507535103

Fontaine S, Henault C, Aamor A, Bdioui N, Bloor JMG, Maire V, Mary B, Revaillot S, Maron PA (2011) Fungi mediate long term sequestration of carbon and nitrogen in soil through their priming effect. Soil Biol Biochem 43:86-96. doi:10.1016/j.soilbio.2010.09.017

Friesen M, Porter SS, Stark SC, von Wettberg EJ, Sachc JL, MartinezRomero E (2011) Microbially mediated plant functional traits. Annu Rev Ecol Evol Syst 42:23-46. doi:10.1146/annurev-ecolsys102710-145039

Gardi C, Montanarella L, Arrouays D, Bispo A, Lemanceau P, Jolivet C, Mulder C, Ranjard L, Roembke J, Rutgers M, Menta C (2009) Soil biodiversity monitoring in Europe: ongoing activities and challenges. Eur J Soil Sci 60:807-819. doi:10.1111/j.1365-2389.2009.01177.x

Gianinazzi S, Gollotte A, Binet MA, van Tuinen D, Redecker D, Wipf D (2010) Agroecology: the key role of arbuscular mycorrhizas in ecosystem services. Mycorrhiza 20:519-530. doi:10.1007/s00572010-0333-3

Girvan MS, Campbell CD, Killham K, Prosser JI, Glover LA (2005) Bacterial diversity promoted community structure stability and functional resilience after perturbation. Environ Microbiol 7:301-313. doi:10.1111/j.1462-2920.2005.00695.x

Gobat JM, Aragno M, Matthey W, Bally R (2010) Le sol vivant. Bases de pédologie, Biologie des sols, 3e édition revue et augmentée. Presses Polytechniques et Universitaires Romandes, Lausanne

Griffiths BS, Philippot L (2013) Insights into the resistance and resilience of the soil microbial community. FEMS Microbiol Rev 37:112-129. doi:10.1111/j.1574-6976.2012.00343.x

Griffiths BS, Ritz K, Bardgett RD, Cook R, Christensen S, Ekelund F, Sorensen SJ, Baath E, Bloem J, de Ruiter PC, Dolfing J, Nicolardot B (2000) Ecosystem response of pasture soil communities to fumigation-induced microbial diversity reductions: an examination of the biodiversity-ecosystem function relationship. Oikos 90:279-294

Griffiths RI, Thomson B, James P, Bell T, Bailey M, Whiteley AS (2011) The bacterial biogeography of British soils. Environ Microbiol 13: 1642-1654. doi:10.1111/j.1462-2920.2011.02480.x

Henault C, Revellin C (2011) Inoculants of leguminous crops for mitigating soil emissions of the greenhouse gas nitrous oxide. Plant Soil 346:289-296. doi:10.1007/s11104-011-0820-0

Herridge DF, Peoples MB, Boddey RM (2008) Global inputs of biological nitrogen fixation in agricultural systems. Plant Soil 311:1-18. doi:10.1007/s11104-008-9668-3

Horwath WR, Paul EA (1994) Microbial biomass. In: Weaver RW (ed) Methods of soil analysis, SSSA book series 5. Soil Sci Soc Am Inc, Madison, pp 727-752

Horz HP, Barbrook A, Field CB, Bohannan BJM (2004) Ammoniaoxidizing bacteria respond to multifactorial global change. Proc Natl Acad Sci U S A 101:15136-15141. doi:10.1073/pnas. 0406616101

INRA (2010) Document d'orientation INRA 2010-2020, une science pour l'impact. INRA, Paris

ISO Standard 11063 (2009) Soil quality - method to directly extract DNA from soil samples. ISO, Genève

Johnson MJ, Lee KY, Scow KM (2003) DNA fingerprinting reveals links among agricultural crops, soil properties, and the composition of soil microbial communities. Geoderma 114:279-303. doi:10.1016/ S0016-7061(03)00045-4

Jones RT, Robeson MS, Lauber CL, Hamady M, Knight R, Fierer N (2009) A comprehensive survey of soil acidobacterial diversity using pyrosequencing and clone library analyses. ISME J 3:442453. doi:10.1038/ismej.2008.127

Lambert H, Mougel C, Jaillard B, Hinsinger P (2009) Plant-microbe-soil interactions in the rhizosphere: an evolutionary perspective. Plant Soil 321:83-115. doi:10.1007/s11104-009-0042-x 
Lata JC, Guillaume K, Degrange V, Abbadie L, Lensi R (2000) Relationships between root density of the African grass Hyparrhenia diplandra and nitrification at the decimetric scale: an inhibition-stimulation balance hypothesis. Proc Biol Sci 267:595600. doi:10.1098/rspb.2000.1043

Lata JC, Degrange V, Raynaud X, Maron PA, Lensi R, Abbadie L (2004) Grass populations control nitrification in savanna soils. Funct Ecol 18:605-611. doi:10.1111/j.0269-8463.2004.00880.x

Lawes JB, Gilbert JH, Warington R (1882) On the amount and composition of the rain and drainage water collected at Rothamsted. Clowes, London. Originally published in J Royal Agr Soc Eng XVII 1881:241-279, 311-350; XVIII 1882:1-71

Leckie SE, Prescott CE, Grayston SJ, Neufeld JD, Mohn WW (2004) Comparison of chloroform fumigation extraction, phospholipid fatty acid, and DNA methods to determine microbial biomass in forest humus. Soil Biol Biochem 36:529-532. doi:10.1016/j. soilbio.2003. 10.014

Lejon DPH, Chaussod R, Ranger J, Ranjard L (2005) Microbial community structure and density under different tree species in an acid forest soil (Morvan, France). Microb Ecol 50:614-625. doi:10.1007/ s00248-005-5130-8

Lejon DPH, Sebastia J, Lamy I, Nowak V, Chaussod R, Ranjard L (2007) Microbial density and genetic structure in two agricultural soils submitted to various organic managements. Microb Ecol 53:650653. doi:10.1007/s00248-006-9145-6

Lemanceau P (2011) EcoFINDERS characterizes biodiversity and functions of soils in Europe 23 partners in 10 European countries and China. Biofutur 326:56-58

Lindstrom K, Murwira M, Willems A, Altier N (2010) The biodiversity of beneficial microbe-host mutualism: the case of rhizobia. Res Microbiol 161:453-463. doi:10.1016/j.resmic.2010.05.005

Loreau M (2000) Biodiversity and ecosystem functioning: recent theoretical advances. Oikos 91:3-17. doi:10.1034/j.1600-0706.2000. 910101.x

Lundberg DS, Lebeis SL, Paredes SH, Yourstone S, Gehring J, Malfatti S, Tremblay J, Engelbrektson A, Kunin V, Rio TGD, Edgar RC, Eickhorst T, Ley RE, Hugenholtz P, Tringe SG, Dangl JL (2012) Defining the core Arabidopsis thaliana root microbiome. Nature 488:86-90. doi:10.1038/nature11237

Manter DK, Delgado JA, Holm DG, Stong RA (2010) Pyrosequencing reveals a highly diverse and cultivar-specific bacterial endophyte community in potato roots. Microb Ecol 60:157-166. doi:10.1007/ s00248-010-9658-x

Maron PA, Ranjard L, Mougel C, Lemanceau P (2007) Metaproteomics: a new approach for studying functional microbial ecology. Microb Ecol 53:486-493. doi:10.1007/s00248-006-9196-8

Maron PA, Mougel C, Ranjard L (2011) Soil microbial diversity: spatial overview, driving factors and functional interest. C R Acad Sci Biol 334:403-411. doi:10.1016/j.crvi.2010.12.003

Marstorp H, Guan X, Gong P (2000) Relationship between dsDNA, chloroformlabile $\mathrm{C}$ and ergosterol in soils of different organic matter contents and $\mathrm{pH}$. Soil Biol Biochem 32:879-882

Mavrodi OV, Mavrodi DV, Thomashow LS, Weller DM (2007) Quantification of 2,4 diacetylphloroglucinol-producing Pseudomonas fluorescens strains in the plant rhizosphere by realtime PCR. Appl Environ Microbiol 73:5531-5538. doi:10.1128/ AEM.00925-07

Mougel C, Maron PA, Philippot L, Ranjard L, Lemanceau P (2011) Translation of metagenomics agroecosystems in ecological services. Biofutur 319:44-47

Naeem S, Li S (1997) Biodiversity enhances ecosystem reliability. Nature 390:507-509. doi:10.1038/37348

Nguyen C (2003) Rhizodeposition of organic C by plants: mechanism and controls. Agronomie 23:375-396. doi:10.1051/agro:2003011

Nicolardot B, Bouziri L, Bastian F, Ranjard L (2007) A microcosm experiment to evaluate the influence of location and quality of plant residues on residue decomposition and genetic structure of soil microbial communities. Soil Biol Biochem 39:1631-1644. doi:10. 1016/j.soilbio.2007.01.012

Peres G, Vandenbulcke F, Guernion M, Hedde M, Beguiristain T, Douay F, Houot S, Piron D, Richard A, Bispo A, Grand C, Galsomies L, Cluzeau D (2011) Earthworm indicators as tools for soil monitoring, characterization and risk assessment. An example from the national Bioindicator programme (France). Pedobiologia 54:S77-S87. doi: 10.1016/j.pedobi.2011.09.015

Petric I, Philippot L, Abbate C, Bispo A, Chesnot T, Hallin S, Laval K, Lebeau T, Lemanceau P, Leyval C, Lindström K, Pandard P, Romero E, Sarr A, Schloter M, Simonet P, Smalla K, Wilke BM, Martin-Laurent F (2011) Inter-laboratory evaluation of the ISO standard 11063 "Soil quality - method to directly extract DNA from soil samples". J Microbiol Meth 84:454 460. doi:10.1016/j.mimet.2011.01.016

Philippot L (2002) Denitrifying genes in bacterial and archaeal genomes. Biochim Biophys Acta 1577:355-376. doi:10.1016/S01674781(02)00420-7

Philippot L, Hallin S (2011) Towards food, feed and energy crops mitigating climate change. Trends Plant Sci 16:476-480. doi:10. 1016/j.tplants.2011.05.00

Philippot L, Abbate C, Bispo A, Chesnot T, Hallin S, Lemanceau P, Lindström K, Pandard P, Romero E, Schloter M, Simonet P, Smalla K, Wilke BM, Petric I, Martin-Laurent F (2010) Soil microbial diversity: an ISO standard for soil DNA extraction. J Soils Sediments 10:1344-1345. doi:10.1007/s11368-010-0265-8

Philippot L, Raaijmakers JM, Lemanceau P, van der Putten WH (2013a) Going back to the roots: the microbial ecology of the rhizosphere. Nat Rev Microbiol 11:789-799. doi:10.1038/nrmicro3109

Philippot L, Spor A, Henault C, Bru D, Bizouard F, Jones CM, Sarr A, Maron PA (2013b) Loss in microbial diversity affects nitrogen cycling in soil. ISME J 7:1609-1619. doi:10.1038/ismej.2013.34

Plassart P, Terrat S, Thomson B, Griffiths R, Dequiedt S, Lelievre M, Regnier T, Nowak V, Bailey M, Lemanceau P, Bispo A, Chabbi A, Maron PA, Mougel C, Ranjard L (2012) Evaluation of the ISO standard 11063 DNA extraction procedure for assessing soil microbial abundance and community structure. PLoS One 7:e44279. doi: 10.1371/journal.pone.0044279

Raaijmakers JM, Weller DM, Thomashow LS (1997) Frequency of antibiotic-producing Pseudomonas spp. in natural environments. Appl Environ Microbiol 63:881-887

Rajendhran J, Gunasekaran P (2008) Strategies for accessing soil metagenome for desired applications. Biotechnol Adv 26:576590. doi:10.1016/j.biotechadv.2008.08.002

Ranjard L, Richaume AS (2001) Quantitative and qualitative microscale distribution of bacteria in soil. Res Microbiol 152:707-716

Ranjard L, Lejon DPH, Mougel C, Schehrer L, Merdinoglu D, Chaussod R (2003) Sampling strategy in molecular microbial ecology: influence of soil sample size on DNA fingerprinting analysis of fungal and bacterial communities. Environ Microbiol 5:1111-1120. doi:10. 1046/j.1462-2920.2003.00521.x

Ranjard L, Echairi A, Nowak V, Lejon DPH, Nouaïm R, Chaussod R (2006) Field and microcosm experiments to evaluate the effects of agricultural copper treatment on the density and genetic structure of microbial communities in two different soils. FEMS Microbiol Ecol 58:303-315. doi:10.1111/j.1574-6941.2006.00157.x

Ranjard L, Dequiedt S, Lelievre M, Maron PA, Mougel C, Morin F, Lemanceau P (2009) Platform GenoSol: a new tool for conserving and exploring soil microbial diversity. Environ Microbiol Rep 1:9799. doi:10.1111/j.1758-2229.2009.00023.x

Ranjard L, Dequiedt S, Jolivet C, Saby NPA, Thioulouse J, Harmand J, Loisel P, Rapaport A, Fall S, Simonet P, Joffre R, Chemidlin-Prévost Bouré N, Maron PA, Mougel C, Martin MP, Toutain B, Arrouays D, Lemanceau P (2010) Biogeography of soil microbial communities: a review and a description of the ongoing French National Initiative. Agron Sustain Dev 30:359-365. doi:10.1051/agro/2009033 
Redecker D, Raab P (2006) Phylogeny of the Glomeromycota (arbuscular mycorrhizal fungi): recent developments and new gene markers. Mycologia 98:885-895. doi:10.3852/mycologia.98.6.885

Redecker D, Kodner R, Graham LE (2000) Glomalean fungi from the Ordovician. Science 289:1920-1921. doi:10.1126/science.289. 5486.1920

Rutgers M, Schouten AJ, Bloem J, van Eekeren N, de Goede RGM, Akkerhuis GAJM, van der Wal A, Mulder C, Brussaard L, Breure AM (2009) Biological measurements in a nationwide soil monitoring network. Eur J Soil Sci 60:820-832. doi:10.1111/j.1365-2389. 2009.01163.x

Schloss PD, Handelsman J (2003) Biotechnological prospects from metagenomics. Curr Opin Biotechnol 14:303-310. doi:10.1016/ S0958-1669(03)00067-3

Smith SE, Read DJ (2008) Mycorrhizal symbiosis, 3rd edn. Academic, San Diego

Smith KP, Handelsman J, Goodman RM (1999) Genetic basis in plants for interactions with disease-suppressive bacteria. Proc Natl Acad Sci U S A 96:4786-4790. doi:10.1073/pnas.96.9.4786

Sprent JI (2008) 60 Ma of legume nodulation. What's new? What's changing? J Exp Bot 59:1081-1084. doi:10.1093/jxb/erm286

Subbarao GV, Nakahara K, Hurtado MP, Ono H, Moreta DE, Salcedo AF, Yoshihashi AT, Ishikawa T, Ishitani M, Ohnishi-Kameyama M, Yoshida M, Rondon M et al (2009) Evidence for biological nitrification inhibition in Brachiaria pastures. Proc Natl Acad Sci U S A 106:17302-17307. doi:10.1073/pnas.0903694106

Tardy V, Mathieu O, Leveque J, Terrat V, Chabbi A, Lemanceau P, Ranjard L, Maron PA (2014) Stability of soil microbial structure and activity depends on microbial diversity. Environ Microbiol Rep 6:173-183. doi:10.1111/1758-2229.12126

Tilman D, Wedin D, Knops J (1996) Productivity and sustainability influenced by biodiversity in grassland ecosystems. Nature 379: 718-720. doi:10.1038/379718a0

Tilman D, Knops J, Wedin D, Reich P, Ritchie M, Siemann E (1997) The influence of functional diversity and composition on ecosystem processes. Science 277:1300-1302. doi:10.1126/science.277.5330. 1300

Torsvik V, Øvreås L (2002) Microbial diversity and function in soil: from genes to ecosystems. Curr Opin Microbiol 5:240-245

Van der Heijden MGA, Klironomos JN, Ursic M, Moutoglis P, StreitwolfEngel R, Boller T, Wiemken A, Sanders IR (1998) Mycorrhizal fungal diversity determines plant biodiversity, ecosystem variability and productivity. Nature 396:69-72. doi:10.1038/23932

Vance ED, Brookes PC, Jenkinson DS (1987) An extraction method for measuring soil microbial biomass C. Soil Biol Biochem 19:703-707

Vogel TM, Simonet P, Jansson JK, Hirsch PR, Tiedje JM, van Elsas JD, Bailey MJ, Nalin R, Philippot L (2009) TerraGenome: a consortium for the sequencing of a soil metagenome. Nat Rev Microbiol 7:252. doi:10.1038/nrmicro2119

Weller DM, Raaijmakers JM, Gardener BB, Thomashow LS (2002) Microbial populations responsible for specific soil suppressiveness to plant pathogens. Annu Rev Phytopathol 40:309-348. doi:10. 1146/annurev.phyto.40.030402.110010

Werner D, Newton WE (2005) Nitrogen fixation in agriculture, forestry, ecology and the environment. Kluwer, Dordrecht

Yachi S, Loreau M (1999) Biodiversity and ecosystem productivity in a fluctuating environment: the insurance hypothesis. Proc Natl Acad Sci U S A 96:1463-1468. doi:10.1073/pnas.96.4.1463

Zancarini A, Mougel C, Terrat S, Salon C, Munier-Jolain N (2013a) Combining ecophysiological and microbial ecological approaches to study the relationship between Medicago truncatula genotypes and their associated rhizosphere bacterial communities. Plant Soil 365:183-199. doi:10.1007/s11104-012-1364-7

Zancarini A, Lépinay C, Burstin J, Duc G, Lemanceau P, Moreau D, Munier-Jolain N, Pivato B, Rigaud T, Salon C, Mougel C (2013b) Combining molecular microbial ecology with ecophysiology and plant genetics for a better understanding of plant-microbial communities interactions in the rhizosphere. Chapter 7. In: de Bruijn FJ (ed) Molecular microbial ecology of the rhizosphere. Wiley, Hoboken, pp 69-86 